\title{
Carbochlorination kinetics of tantalum and niobium pentoxides ${ }^{(\bullet)}$
}

\author{
E. Allain $(*)$, I. Gaballah $^{(* *)}$, F. García $(* * *)$, S. Ferreira $(* * *)$, J.N. Ayala ${ }^{(* *)}$ \\ y A. Hernández $(* * *)$
}

\begin{abstract}
The carbochlorination kinetics of pure $\mathrm{Nb}_{2} \mathrm{O}_{5}$ and $\mathrm{Ta}_{2} \mathrm{O}_{5}$ by gas mixture $\left(\mathrm{Cl}_{2}+\mathrm{CO}+\mathrm{N}_{2}\right)$ between 380 and $1,000{ }^{\circ} \mathrm{C}$ is studied. A calculation of the standard free energy of the carbochlorination reactions is made. A diagram of the phases stability is drawn. The influence of the gas flow, temperature and the partial pressure of $\mathrm{Cl}_{2}$ and $\mathrm{CO}$ at temperatures below $650{ }^{\circ} \mathrm{C}$ on the reaction rate is studied. The apparent activation energy is approximately 75 and $110 \mathrm{~kJ} / \mathrm{mol}$ for $\mathrm{Nb}_{2} \mathrm{O}_{5}$ and $\mathrm{Ta}_{2} \mathrm{O}_{5}$, respectively. At temperatures above $650^{\circ} \mathrm{C}$ the Arrhenius diagram presents an anomaly which may be attributed to the decomposition of the $\mathrm{COCl}_{2}$ formed in situ. The apparent reaction order of the carbochlorination of these oxides against $\mathrm{Cl}_{2}+\mathrm{CO}$ is approximately 2 . The carbochlorination rates of these oxides are much greater than those of chlorination by $\mathrm{Cl}_{2}+\mathrm{N}_{2}$. The carbochlorination kinetics of tin furnace slag leaching concentrates containing tantalum and niobium compounds are also studied and compared with the carbochlorination kinetics of the pure oxides.
\end{abstract}

Keywords: Carbochlorination. Tantalum pentoxide. Niobium pentoxide. Tin furnace slag.

\section{Cinética de carbocloruración de los pentóxidos de tantalio y de niobio}

\begin{abstract}
Resumen En este trabajo se estudia la cinética de carbocloruración del $\mathrm{Nb}_{2} \mathrm{O}_{5}$ y del $\mathrm{Ta}_{2} \mathrm{O}_{5}$ por la mezcla de gases $\left(\mathrm{Cl}_{2}+\mathrm{CO}+\mathrm{N}_{2}\right)$ entre 380 y $1000{ }^{\circ} \mathrm{C}$. Se hace un cálculo de la energía libre estandar de carbocloruración y se dibujan los diagramas de equilibrio de fases. Se estudia la influencia del flujo de gas, la temperatura y la presión parcial de $\mathrm{Cl}_{2}$ y $\mathrm{CO}$ a temperaturas por debajo de $650{ }^{\circ} \mathrm{C}$ sobre la velocidad de reacción. La energía de activación es aproximadamente 75 y $110 \mathrm{~kJ} / \mathrm{mol}$ para el $\mathrm{Nb}_{2} \mathrm{O}_{5}$ y el $\mathrm{Ta}_{2} \mathrm{O}_{5}$, respectivamente. A temperaturas por encima de $650{ }^{\circ} \mathrm{C}$, el diagrama de Arrhenius presenta una anomalía que puede ser atribuida a la descomposición del $\mathrm{COCl}_{2}$ formado in situ. El orden aparente de reacción de la carbocloruración de estos óxidos frente a $\mathrm{Cl}_{2}+\mathrm{CO}$ es aproximadamente 2. La velocidad de carbocloruración de estos óxidos es mucho más grande que la que se conseguía con una mezcla de $\mathrm{Cl}_{2}$ y $\mathrm{N}_{2}$. Se ha comparado la cinética de carboclururación de los compuestos de niobio y tantalio contenidos en los concentrados de lixiviación de las escorias de hornos de estaño con la cinética de carbocloruración de los óxidos puros.
\end{abstract}

Palabras clave: Carbocloruración. Pentóxido de tantalio. Pentóxido de niobio. Escorias de horno de estaño.

\section{INTRODUCTION}

The tantalum and niobium metals have applications in advanced technologies such as electronics,

$(\bullet \quad$ Trabajo recibido el día 17 de febrero de 1999 y aceptado en su forma final el 8 de julio de 1999.

(*) University of Missouri-Rolla, School of Mines and Metallurgy. Center of Pyrometallurgy. 210 Fulton Hall, 65409 Rolla, MO (EE.UU.)

(**) Laboratoire Environnement et Minéralurgie LEM. Rue du Doyen Marcel Roubault, 54501, Vandoeuvre, Cedex (Francia).

(****) Centro Nacional de Investigaciones Metalúrgicas, CENIM (CSIC). Avda. Gregorio del Amo, 8. 28040Madrid (España). superconductivity and in the aerospace industry. They are used as alloying elements in superalloys and even in high definition television, etc ( 1 y 2$)$.

Current methods of tantalum and niobium extraction, from minerallurgical concentrates or from tin furnace slags, are often polluting or costly (3 y 4). These reasons have led several teams to research different possibilities for recovering these elements. The line considered by our team consists of the selective leaching of slags followed by the carbochlorination of the concentrate obtained (5). Complementing data from the literature (6 y 7), the aim of the study presented below has been to better understand the mechanisms susceptible to 
controlling the carbochlorination reactions of pure $\mathrm{Ta}_{2} \mathrm{O}_{5}$ and $\mathrm{Nb}_{2} \mathrm{O}_{5}$ and in this way improve their extraction from leaching concentrates.

\section{EXPERIMENTAL METHOD}

The carbochlorination kinetics of $\mathrm{Nb}_{2} \mathrm{O}_{5}$ and $\mathrm{Ta}_{2} \mathrm{O}_{5}$ have been studied by thermogravimetric analysis using a CAHN thermobalance, model C 1000, with a sensitivity of $0.01 \mathrm{mg}$. The tests were carried out using a $100 \mathrm{mg}$ sample in the interval of temperatures from 20 to $1000{ }^{\circ} \mathrm{C}$. The tests finalized when the sample ceased to lose weight.

For these tests samples were taken of pure tantalum and niobium oxides in powder form, whose characteristics are shown in Table I.

These oxides have been used without any prior treatment.

When tin furnace slags are leached two concentrates are obtained, one with a high content of tantalum and niobium compounds, which we call rich concentrate, CR, and another with a lesser content which we call poor concentrate CP. Table II shows the chemical composition of these concentrates.

\section{RESULTS AND DISCUSSION}

\subsection{Thermodynamic study}

The main carbochlorination reactions of the tantalum and niobium oxides are given by equations [1] to [6]:

$$
\begin{array}{rrr}
\mathrm{Nb}_{2} \mathrm{O}_{5}+\mathrm{Cl}_{2}+\mathrm{CO} \rightarrow & 2 \mathrm{Nb}_{2} \mathrm{Cl}+\mathrm{CO}_{2} \\
1 / 3 \mathrm{Nb}_{2} \mathrm{O}_{5}+\mathrm{Cl}_{2}+\mathrm{CO} \rightarrow & 2 / 3 \mathrm{NbOCl}_{3}+\mathrm{CO}_{2} \\
1 / 5 \mathrm{Nb}_{2} \mathrm{O}_{5}+\mathrm{Cl}_{2}+\mathrm{CO} \rightarrow & 2 / 5 \mathrm{NbCl}_{5}+\mathrm{CO}_{2} \\
\mathrm{Ta}_{2} \mathrm{O}_{5}+\mathrm{Cl}_{2}+\mathrm{CO} \rightarrow & 2 \mathrm{TaO}_{2} \mathrm{Cl}+\mathrm{CO}_{2} \\
1 / 3 \mathrm{Ta}_{2} \mathrm{O}_{5}+\mathrm{Cl}_{2}+\mathrm{CO} \rightarrow & 2 / 3 \mathrm{TaOCl}_{3}+\mathrm{CO}_{2} \\
1 / 5 \mathrm{Ta}_{2} \mathrm{O}_{5}+\mathrm{Cl}_{2}+\mathrm{CO} \rightarrow & 2 / 5 \mathrm{TaCl}_{5}+\mathrm{CO}_{2}
\end{array}
$$

TABLE I.- Some characteristics of the pure $\mathrm{Ta}_{2} \mathrm{O}_{5}$ and $\mathrm{Nb}_{2} \mathrm{O}_{5}$ powders

TABLA I.- Algunas características de los polvos $\mathrm{Ta}_{2} \mathrm{O}_{5}$ y $\mathrm{Nb}_{2} \mathrm{O}_{5}$ en estado puro

\begin{tabular}{|c|c|c|}
\hline Oxides, $\%$ & $\mathrm{Nb}_{2} \mathrm{O}_{5},>99.4$ & $\mathrm{Ta}_{2} \mathrm{O}_{5},>99$ \\
\hline JCPDS$^{*}$ file & $27-1003$ & $25-922$ \\
\hline
\end{tabular}

* JCPDS = Joint Committee for Powder Diffraction Standard.

All the thermodynamic data presented in this article are calculated from the HSC database (8). Figure 1 shows the standard free energy evolution of the carbochlorination reactions of tantalum and niobium oxides between 0 and $1,000{ }^{\circ} \mathrm{C}$. All the reactions considered are thermodynamically possible.

Figure 2 shows the stability diagram of the compounds in the $\mathrm{Ta}-\mathrm{O}-\mathrm{Cl}$ and $\mathrm{Nb}-\mathrm{O}-\mathrm{Cl}$ systems at

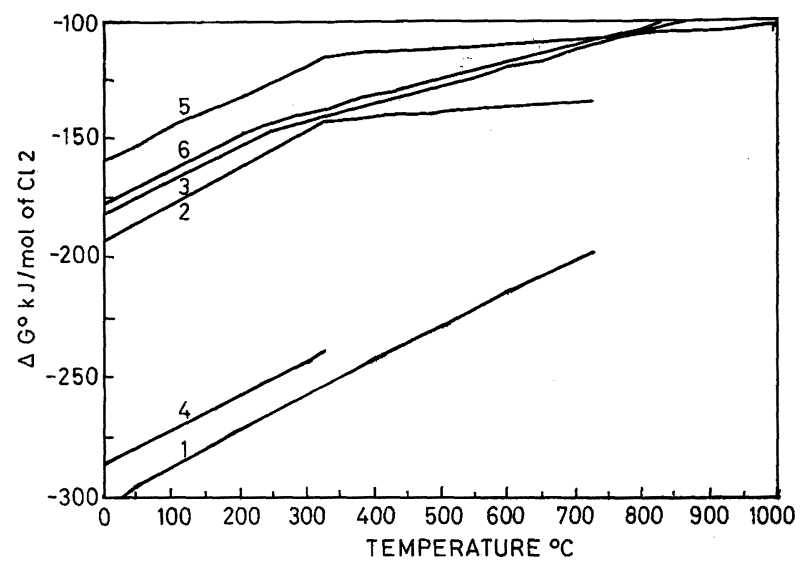

FIG. 1.- Free energy of carbochlorination of $\mathrm{Nb}_{2} \mathrm{O}_{5}$ and $\mathrm{Ta}_{2} \mathrm{O}_{5}$ as a function of temperature.

FIG. 1.- Energía libre de carbocloruración del $\mathrm{Nb}_{2} \mathrm{O}_{5}$ y del $\mathrm{Ta}_{2} \mathrm{O}_{5}$ en función de la temperatura.

TABLE II.- Chemical composition of the tin furnace slags and of the leaching concentrates TABLA II.-Composición química de las escorias de horno de estaño y de los concentrados de lixiviación

\begin{tabular}{|l|c|c|c|c|c|c|c|c|c|c|}
\hline Oxide, \% & $\mathrm{Nb}_{2} \mathrm{O}_{5}$ & $\mathrm{Ta}_{2} \mathrm{O}_{5}$ & $\mathrm{SiO}_{2}$ & $\mathrm{CaO}$ & $\mathrm{FeO}$ & $\mathrm{Al}_{2} \mathrm{O}_{3}$ & $\mathrm{SnO}_{2}$ & $\mathrm{MnO}$ & $\mathrm{K}_{2} \mathrm{O}$ & $\mathrm{TiO}_{2}$ \\
\hline Brut. $^{+}$ & 5.2 & 7.5 & 41.9 & 11.6 & 3.3 & 11.2 & 0.7 & 3.7 & 1.4 & 1.3 \\
$\mathrm{CP}^{*}$ & 7.7 & 15.6 & 43.3 & 9.8 & 2.5 & 5.2 & 0.9 & 2.3 & 0.8 & 1.2 \\
$\mathrm{CR}^{* *}$ & 28.0 & 31.1 & 10.0 & 0.6 & 0.2 & 0.6 & 0.2 & 0.0 & 0.4 & 1.4 \\
\hline
\end{tabular}

+ Tin furnace slags.

* Poor concentrate CP.

*** Rich concentrate CR. 

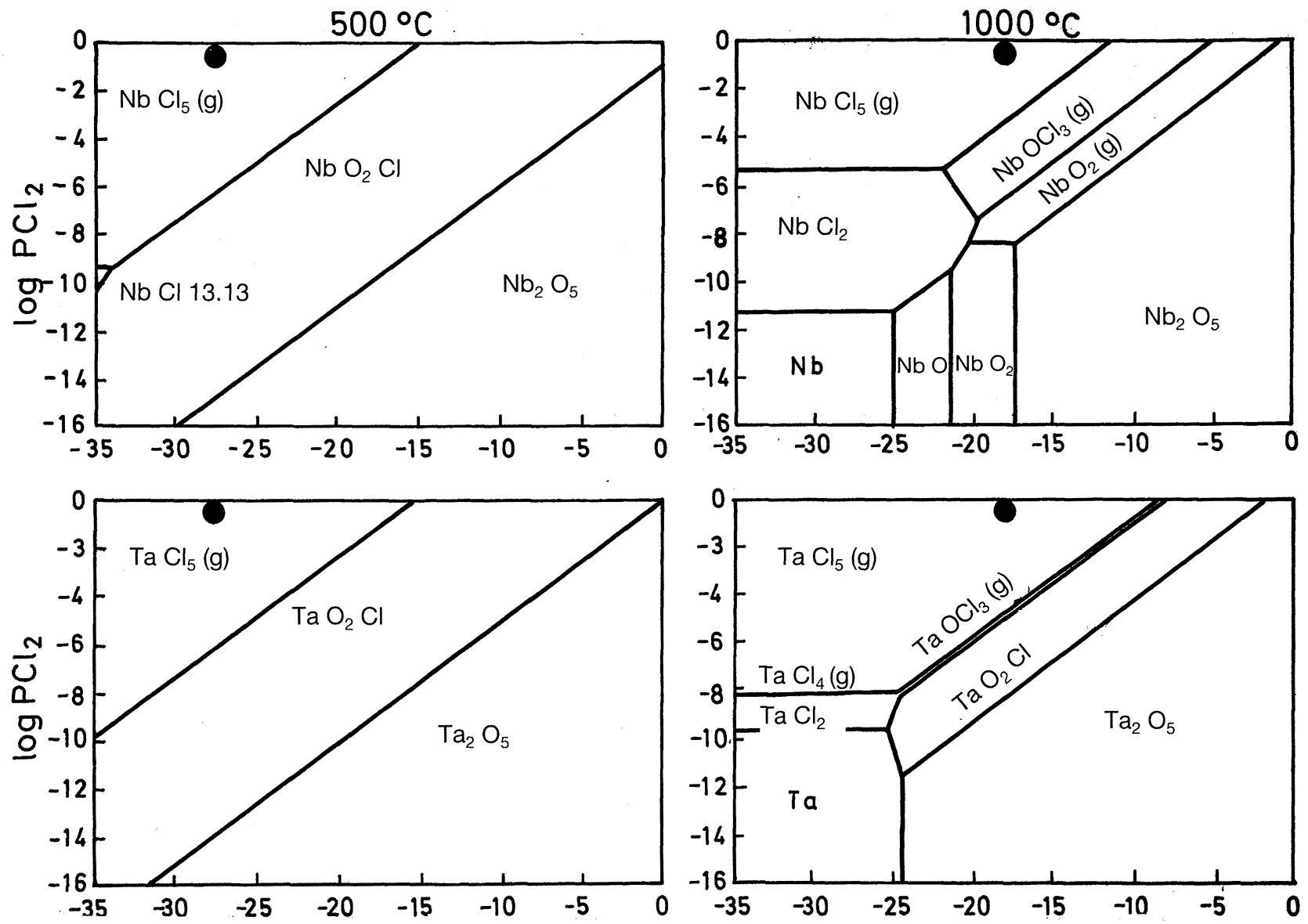

FIG. 2. - Phase diagram of (Mo, Nb, Ta and V)-O-Cl at 500 and $1,000{ }^{\circ} \mathrm{C}$.

FIG. 2.-Diagrama de fases del ( $\mathrm{Mo}, \mathrm{Nb}, \mathrm{Ta}$ y V)-O-Cl a 500 y $1.000{ }^{\circ} \mathrm{C}$.

500 and $1,000 \quad{ }^{\circ} \mathrm{C}$. The experimental carbochlorination conditions, shown by black dots, indicate that the most probable carbochlorination products are $\mathrm{NbCl}_{5}$ for $\mathrm{Nb}_{2} \mathrm{O}_{5}$ and $\mathrm{TaCl}_{5}$ for $\mathrm{Ta}_{2} \mathrm{O}_{5}$.

\subsection{Influence of heating and of the gas flow}

As can be seen in figure $3, \mathrm{Nb}_{2} \mathrm{O}_{5}$ and $\mathrm{Ta}_{2} \mathrm{O}_{5}$ start to react with $\mathrm{Cl}_{2}+\mathrm{CO}+\mathrm{N}_{2}$ at around 400 and 500 ${ }^{\circ} \mathrm{C}$, respectively. It should be noted that the carbochlorination kinetics of $\mathrm{Ta}_{2} \mathrm{O}_{5}$ are similar to those of $\mathrm{Nb}_{2} \mathrm{O}_{5}$.

Figure 4 shows the influence of the flow of $\mathrm{Cl}_{2}$ $+\mathrm{CO}+\mathrm{N}_{2}$ on the carbochlorination rate of $\mathrm{Nb}_{2} \mathrm{O}_{5}$ and $\mathrm{Ta}_{2} \mathrm{O}_{5}$. An increase in the chlorination rate is seen in the tests as the flow of chlorinating mixture increases, much more pronounced in the case of tantalum oxide than for niobium oxide. This tendency is maintained until the test reaches a flow of $30 \mathrm{~L} / \mathrm{h}$, after which the chlorination rate does not increase whatever the increase in the flow. The effects of the transfer of mass may be reduced to a minimum, using this flow, which corresponds to a speed of gases with respect to the sample of 0.35

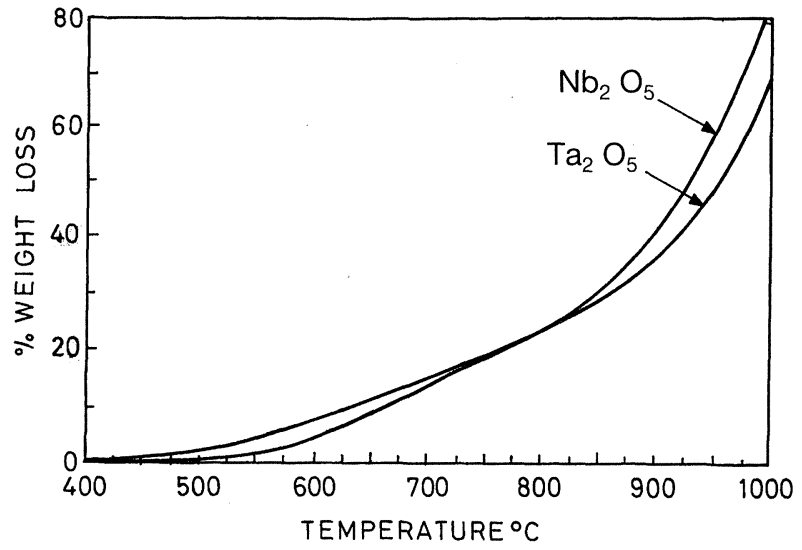

FIG. 3.- Carbochlorination of $\mathrm{Nb}_{2} \mathrm{O}_{5}$ and $\mathrm{Ta}_{2} \mathrm{O}_{5}$ as a function of temperature.

FIG. 3.- Carbocloruración de $\mathrm{Nb}_{2} \mathrm{O}_{5}$ y $\mathrm{Ta}_{2} \mathrm{O}_{5}$ en función de la temperatura.

$\mathrm{cm} / \mathrm{s}$. The use of this flow makes it possible to determine the intrinsic parameters of the carbochlorination of $\mathrm{Nb}_{2} \mathrm{O}_{5}$ and $\mathrm{Ta}_{2} \mathrm{O}_{5}$, and to eliminate the effects of the transfer of matter between the gas mixture and the solids. 


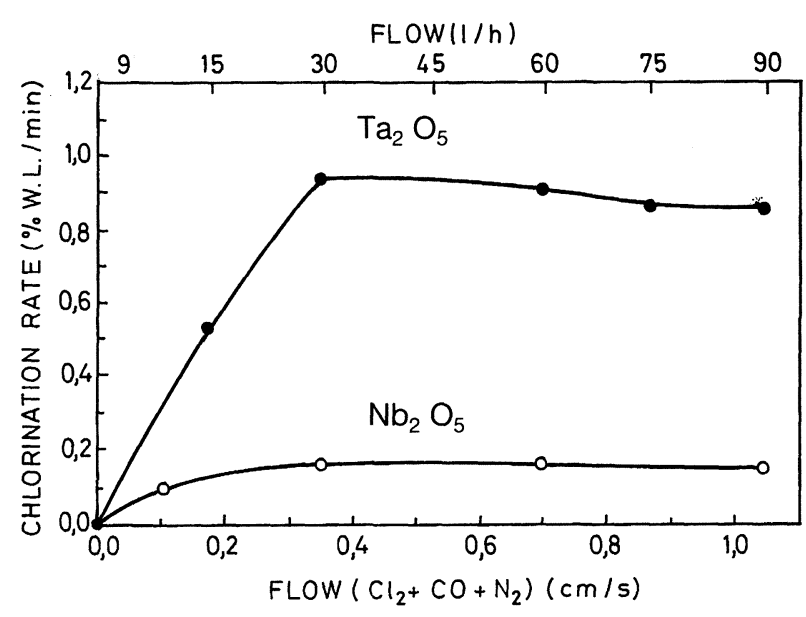

FIG. 4.- Influence of the flow on the carbochlorination rate of $\mathrm{Nb}_{2} \mathrm{O}_{5}$ and $\mathrm{Ta}_{2} \mathrm{O}_{5}$.

FIG. 4.- Influencia del caudal sobre la velocidad de carbocloruración del $\mathrm{Nb}_{2} \mathrm{O}_{5}$ y $\mathrm{Ta}_{2} \mathrm{O}_{5}$.

\subsection{Influence of the partial pressure of the reagents}

Figure 5 represents the logarithm of the carbochlorination rate of $\mathrm{Nb}_{2} \mathrm{O}_{5}$ and $\mathrm{Ta}_{2} \mathrm{O}_{5}(\mathrm{LnR})$, as a function of the partial pressure of the gas mixture $\left(\mathrm{Cl}_{2}+\mathrm{CO}\right)$. In both cases the apparent order of reaction is equal or close to 2 . This value generally indicates the existence of a bimolecular reaction between the gaseous reagents themselves. For the present case the following reaction [7] may be considered:

$$
\begin{gathered}
\mathrm{CO}(\mathrm{g})+\mathrm{Cl}_{2}(\mathrm{~g}) \rightarrow \mathrm{COCl}_{2}(\mathrm{~g}) ; \\
\Delta \mathrm{G}^{\circ}\left(500^{\circ} \mathrm{C}\right)=-3.6 \mathrm{~kJ} / \mathrm{mol}
\end{gathered}
$$

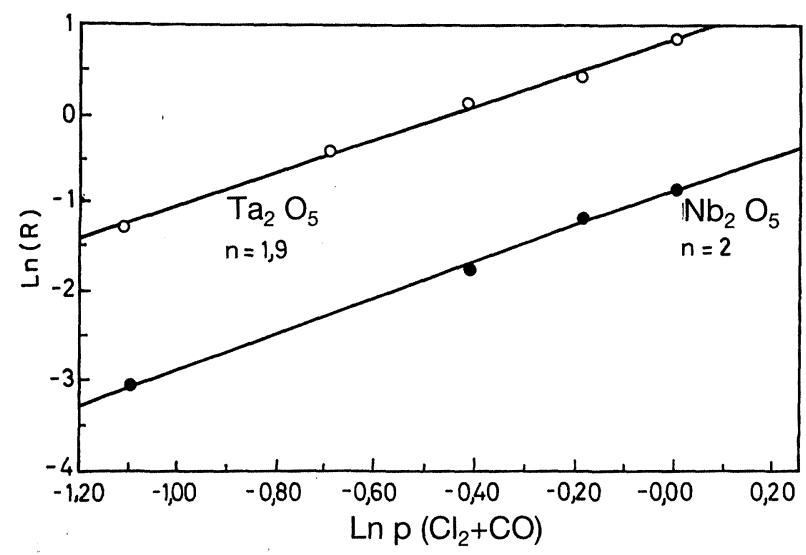

FIG. 5.- Effect of $\mathrm{p}_{(\mathrm{Cl} 2+\mathrm{CO})}$ on the carbochlorination rate of $\mathrm{Nb}_{2} \mathrm{O}_{5}$ and $\mathrm{Ta}_{2} \mathrm{O}_{5}$.

FIG. 5.- Efecto de $\mathrm{p}_{\left(\mathrm{Cl}_{2}+\mathrm{CO}\right)}$ sobre la velocidad de carbocloruración del $\mathrm{Nb}_{2} \mathrm{O}_{5}$ y $\mathrm{Ta}_{2} \mathrm{O}_{5}$.

\subsection{Influence of the $\mathbf{p}_{\mathrm{C} 2} / \mathbf{p}_{\mathrm{CO}}$ relation}

Figure 6 shows that the maximum carbochlorination rate of $\mathrm{Nb}_{2} \mathrm{O}_{5}$ and $\mathrm{Ta}_{2} \mathrm{O}_{5}$ is obtained when $\mathrm{p}_{\mathrm{Cl} 2} / \mathrm{p}_{\mathrm{CO}}=1$. This result confirms that the carbochlorination mechanism of $\mathrm{Nb}_{2} \mathrm{O}_{5}$ and $\mathrm{Ta}_{2} \mathrm{O}_{5}$ is equimolar with regard to $\mathrm{Cl}_{2}$ and $\mathrm{CO}$. On the other hand, it has been seen that neither of these two oxides is reduced by $\mathrm{CO}$ at temperatures lower than 420 and $600{ }^{\circ} \mathrm{C}$, respectively. However, their chlorination will only commence in the presence of a small quantity of $\mathrm{CO}$.

\subsection{Effect of temperature}

Two series of carbochlorination isotherms have been realized for $\mathrm{Nb}_{2} \mathrm{O}_{5}$ and $\mathrm{Ta}_{2} \mathrm{O}_{5}$ between 380 and $1,000{ }^{\circ} \mathrm{C}$ (Fig. 7). On the basis of this data the corresponding Arrhenius diagram has been obtained (Fig. 8), which indicates that the apparent activation energies are 74 and $78 \mathrm{~kJ} / \mathrm{mol}$ for the carbochlorination of $\mathrm{Nb}_{2} \mathrm{O}_{5}$, between 380 and $600{ }^{\circ} \mathrm{C}$ and between 800 and $1,000{ }^{\circ} \mathrm{C}$, respectively. The best correlations obtained in these two temperature intervals have been with the function $k_{\mathrm{t}}=1-(1-X)^{1 / 3}$ (Fig. 9). This relation describes the complete gasification in a porous sphere, when the mechanism is controlled by the diffusion in the pores. This may be equally adequate, in the case of a non-porous sphere, with a chemically controlled gasification mechanism (9). In the case of $\mathrm{Nb}_{2} \mathrm{O}_{5}$, bearing in mind the values of the apparent activation energies, the first hypothesis seems the most appropriate.

The Arrhenius diagram represented in figure 8 indicates that the apparent activation energies for

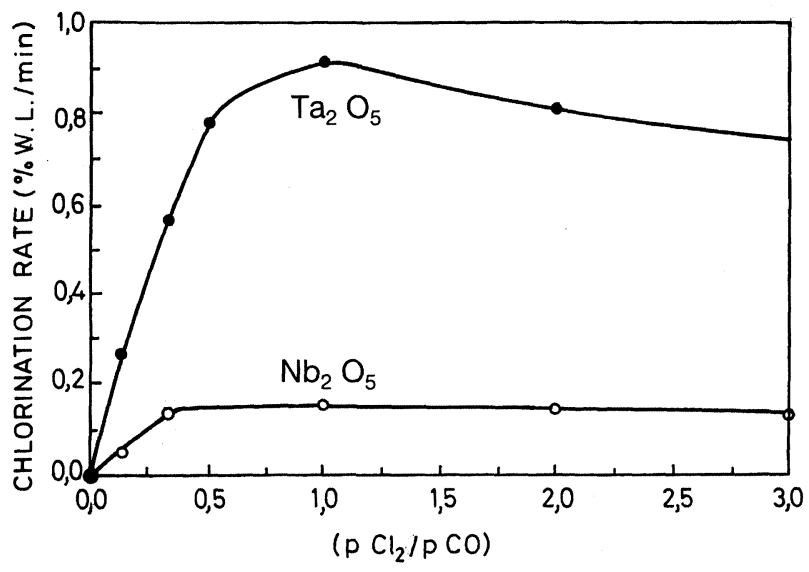

FIG. 6.- Effect of the $\mathrm{Cl}_{2} / \mathrm{CO}$ ratio on the carbochlorination rate of $\mathrm{Nb}_{2} \mathrm{O}_{5}$ and $\mathrm{Ta}_{2} \mathrm{O}_{5}$.

FIG. 6.- Efecto de la relación $\mathrm{Cl}_{2} / \mathrm{CO}$ sobre la velocidad de carbocloruración del $\mathrm{Nb}_{2} \mathrm{O}_{5}$ y $\mathrm{Ta}_{2} \mathrm{O}_{5}$. 

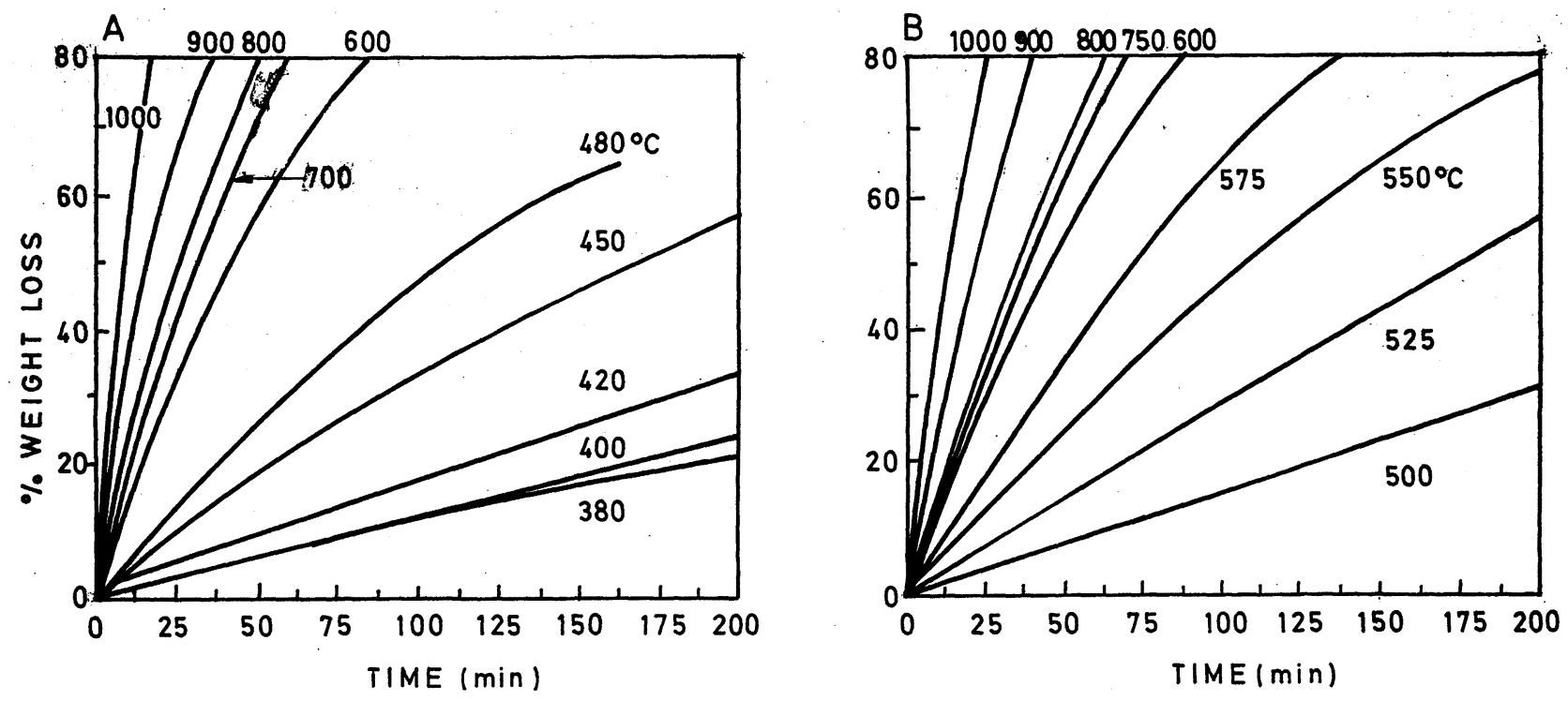

FIG. 7.- Carbochlorination isotherms for $\mathrm{Nb}_{2} \mathrm{O}_{5}$ (A) and $\mathrm{Ta}_{2} \mathrm{O}_{5}$ (B).

FIG. 7.-Isotermas de carbocloruración para $\mathrm{Nb}_{2} \mathrm{O}_{5}(\mathrm{~A})$ y $\mathrm{Ta}_{2} \mathrm{O}_{5}(\mathrm{~B})$.

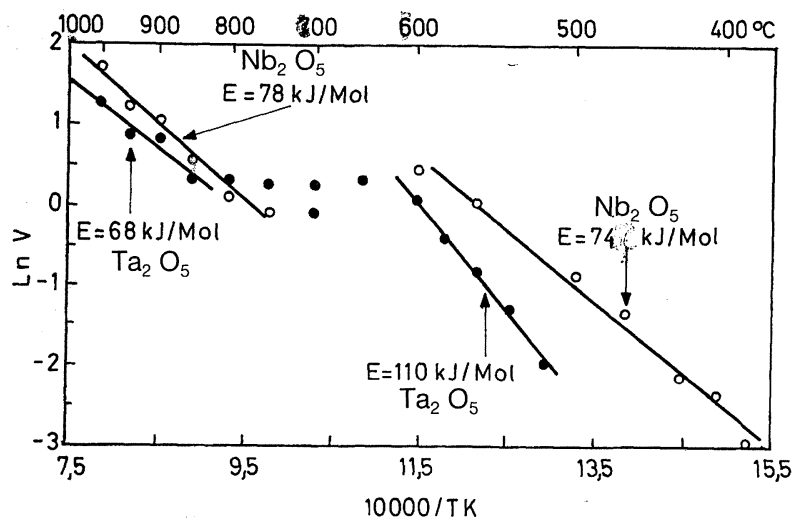

FIG. 8.- Arrhenius diagram of the carbochlorination of $\mathrm{Nb}_{2} \mathrm{O}_{5}$ and $\mathrm{Ta}_{2} \mathrm{O}_{5}$.

FIG. 8.-Diagrama de Arrhenius de la carbocloruración del $\mathrm{Nb}_{2} \mathrm{O}_{5}$ y $\mathrm{Ta}_{2} \mathrm{O}_{5}$.

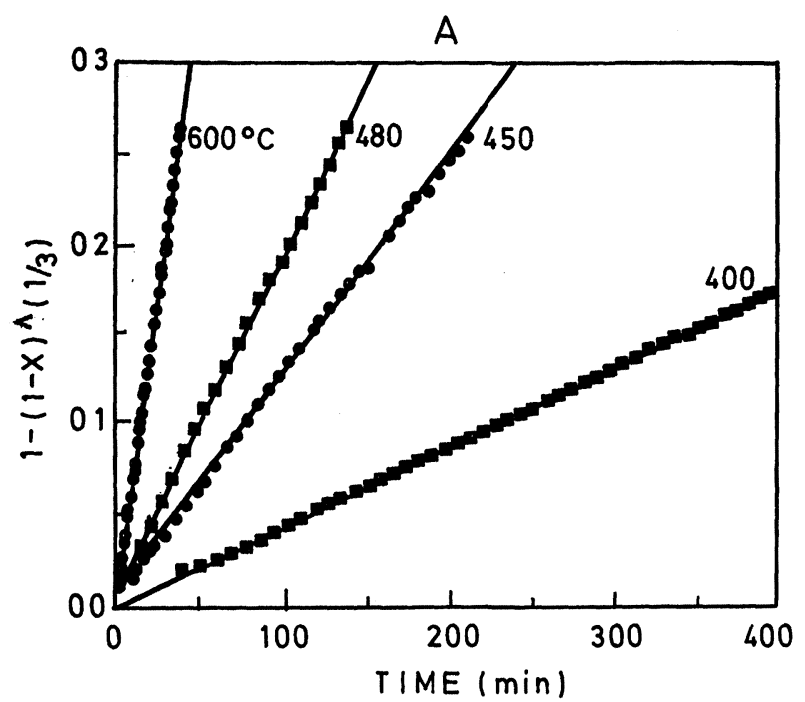

$\mathrm{Ta}_{2} \mathrm{O}_{5}$, are 110 and $68 \mathrm{~kJ} / \mathrm{mol}$ between 500 and $600^{\circ} \mathrm{C}$ and between 850 and $1,000{ }^{\circ} \mathrm{C}$, respectively. In both cases the best correlations have been obtained with the relation $k_{\mathrm{t}}=1-(1-X)^{1 / 2}$. This function is susceptible to representing the complete gasification of a porous cylinder in agreement with a mechanism affected by the diffusion in the pores (9). Bearing in mind the values of the apparent activation energies, it seems that between 500 and $600{ }^{\circ} \mathrm{C}$ the carbochlorination of $\mathrm{Ta}_{2} \mathrm{O}_{5}$ is controlled by the chemical reaction, while between 850 and $1,000{ }^{\circ} \mathrm{C}$, the diffusion in the pores interferes with the chemical reaction.

Figure 8 also shows the existence of an important anomaly in the speed between 600 and $800{ }^{\circ} \mathrm{C}$. This minimum of speed has also been

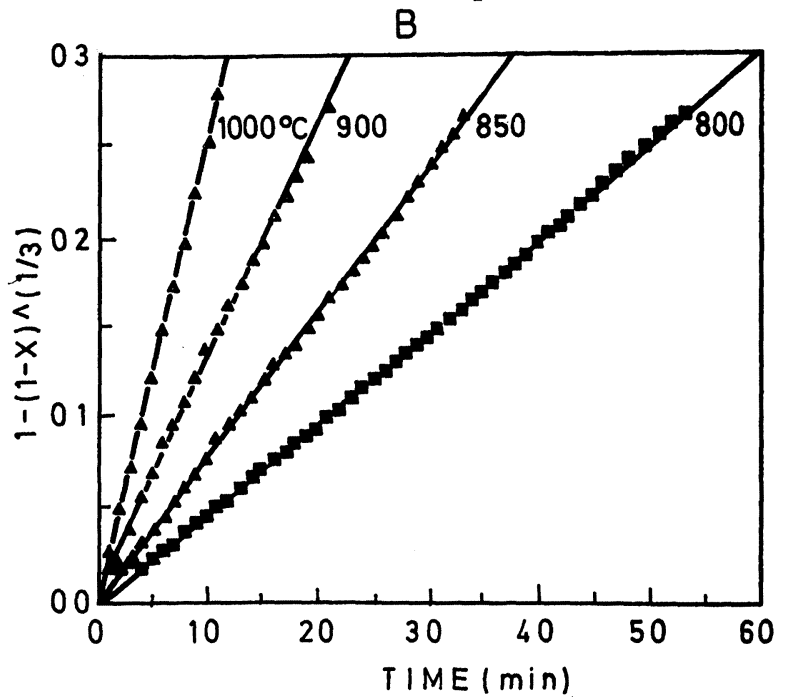

FIG. 9.- Function 1-(1-X) ${ }^{1 / 3}$ against time for the carbochlorination of $\mathrm{Nb}_{2} \mathrm{O}_{5}$ at $T<600$ (A) and $\mathrm{T}>800{ }^{\circ} \mathrm{C}(\mathrm{B})$.

FIG. 9.- Función 1-(1-X $)^{1 / 3}$ frente al tiempo para la carbocloruración del $\mathrm{Nb}_{2} \mathrm{O}_{5}$ a $\mathrm{T}<600$ (A) y a $\mathrm{T}>$ $800^{\circ} \mathrm{C}(\mathrm{B})$. 
detected during the carbochlorination of oxides such as $\mathrm{Al}_{2} \mathrm{O}_{3}, \mathrm{ZrO}_{2}, \mathrm{Nb}_{2} \mathrm{O}_{5}$ and $\mathrm{V}_{2} \mathrm{O}_{5}$ (10-13) by the $\mathrm{Cl}_{2}+\mathrm{CO}$ mixture. This phenomenon is attributed to the presence of $\mathrm{COCl}_{2}$ in this chlorinating mixture. Indeed, this compound may be synthesized in situ and be the predominant chlorinating agent at $T<600{ }^{\circ} \mathrm{C}$. Its progressive decomposition as a function of the temperature (Fig. 10) probably gives rise to another carbochlorination mechanism at $T>800^{\circ} \mathrm{C}$.

Table III shows the rates $R$ of carbochlorination by $\mathrm{Cl}_{2}+\mathrm{CO}+\mathrm{N}_{2}$ and chlorination by $\mathrm{Cl}_{2}+\mathrm{N} 2$ (14) of $\mathrm{Nb}_{2} \mathrm{O}_{5}$ and $\mathrm{Ta}_{2} \mathrm{O}_{5}$, respectively, as a function of the temperature. These values vary between 164 and 8.2, diminishing as the temperature increases. The production of chlorinated compounds of tantalum and niobium will be more efficient by carbochlorination than by chlorination, above all at low temperatures.

\subsection{Leaching concentrates}

Carbochlorination isotherms have also been carried out on poor $\mathrm{CP}$ and rich $\mathrm{CR}$ leaching concentrates, containing approximately 23.3 and $60 \%(\mathrm{Nb}+$ $\mathrm{Ta})_{2} \mathrm{O}_{5}$, respectively. The Arrhenius diagram in figure 11 indicates that the carbochlorination kinetics of the rich concentrate are faster than those of the poor concentrate. On the other hand, comparison with figure 8 indicates that the carbochlorination rate of the rich concentrate is of the same order as that of pure $\mathrm{Nb}_{2} \mathrm{O}_{5}$ and $\mathrm{Ta}_{2} \mathrm{O}_{5}$, while that of the poor concentrate is clearly lower.

At temperatures $<600{ }^{\circ} \mathrm{C}$, the apparent activation energy of the carbochlorination of the poor concentrate and the rich concentrate are 115.5 and $103 \mathrm{~kJ} / \mathrm{mol}$, respectively. In this interval of

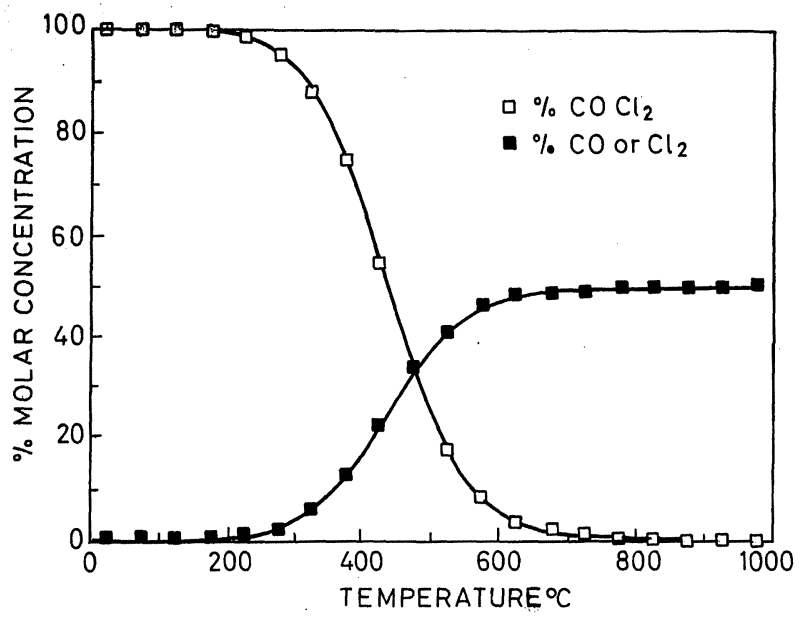

FIG. 10.- Dissociation of $\mathrm{COCl}_{2}$ as a function of the temperature.

FIG. 10.-Disociación del $\mathrm{COCl}_{2}$ en función de la temperatura.
TABLE III.- Evolution of the rates $R$ of carbochlorination and chlorination of $\mathrm{Nb}_{2} \mathrm{O}_{5}$ and $\mathrm{Ta}_{2} \mathrm{O}_{5}$, as a function of temperature

TABLA III.- Evolución de las relaciones $\mathrm{R}$ de carbocloruración y cloruración del $\mathrm{Nb}_{2} \mathrm{O}_{5}$ y $\mathrm{Ta}_{2} \mathrm{O}_{5}$ en función de la temperatura.

\begin{tabular}{|c|r|c|}
\hline \multirow{2}{*}{$T,{ }^{\circ} \mathrm{C}$} & \multicolumn{2}{|c|}{$R$} \\
\cline { 2 - 3 } & $\mathrm{Nb}_{2} \mathrm{O}_{5}$ & $\mathrm{Ta}_{2} \mathrm{O}_{5}$ \\
\hline 679 & 164.0 & - \\
780 & 17.3 & - \\
903 & 8.6 & 121.5 \\
1,060 & 8.2 & 13.5 \\
\hline
\end{tabular}

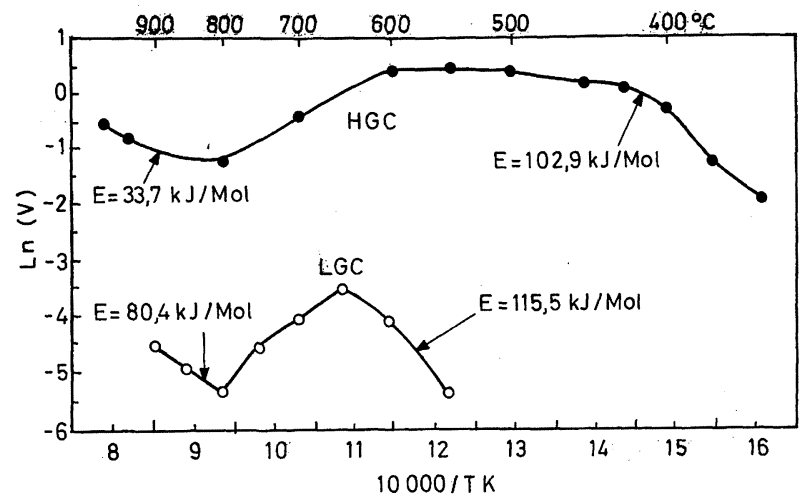

FIG. 11.- Arrhenius diagram of the carbochlorination of the poor and rich concentrates.

FIG. 11.- Diagrama de Arrhenius de la carbocloruración de los concentrados pobre y rico.

temperatures the carbochlorination process of these solids seems to be controlled by the chemical reaction.

Between 600 and $800{ }^{\circ} \mathrm{C}$, an anomaly is observed similar to that found for pure $\mathrm{Nb}_{2} \mathrm{O}_{5}$ and $\mathrm{Ta}_{2} \mathrm{O}_{5}$. The presence of $\mathrm{COCl}_{2}$ in the gaseous mixture seems to be the origin of this phenomenon. The formation of calcium chlorides and/or solid and liquid manganese in the poor concentrate may contribute to causing this minimum in the rate.

At temperatures above $800{ }^{\circ} \mathrm{C}$, it is likely that the diffusion in the pores affects the carbochlorination mechanism of these two concentrates.

\section{CONCLUSIONS}

- At temperatures below $600{ }^{\circ} \mathrm{C}$, the apparent energies of the carbochlorination of $\mathrm{Nb}_{2} \mathrm{O}_{5}$ and $\mathrm{Ta}_{2} \mathrm{O}_{5}$ are 74 and $110 \mathrm{~kJ} / \mathrm{mol}$, respectively. The 
controlling mechanism seems to be the diffusion in the pores, in the first case, and the chemical reaction in the second.

- An anomaly in the rate is observed in the Arrhenius diagram of the carbochlorination of $\mathrm{Nb}_{2} \mathrm{O}_{5}$ and $\mathrm{Ta}_{2} \mathrm{O}_{5}$ between 600 and $800{ }^{\circ} \mathrm{C}$, probably due to the dissociation of the $\mathrm{COCl}_{2}$.

- Between $850{ }^{\circ} \mathrm{C}$ and $1,000{ }^{\circ} \mathrm{C}$ the apparent activation energy is $78 \mathrm{~kJ} / \mathrm{mol}$ for $\mathrm{Nb}_{2} \mathrm{O}_{5}$ and 68 $\mathrm{kJ} / \mathrm{mol}$ for $\mathrm{Ta}_{2} \mathrm{O}_{5}$. The reaction rates of the two oxides are probably controlled by the chemical reaction affected by the diffusion in the pores.

- Above $600{ }^{\circ} \mathrm{C}$ the apparent order of the carbochlorination of $\mathrm{Nb}_{2} \mathrm{O}_{5}$ and $\mathrm{Ta}_{2} \mathrm{O}_{5}$ against $\mathrm{p}_{(\mathrm{Cl} 2+\mathrm{CO})}$ is approximately 2 .

- The maximum carbochlorination rate of $\mathrm{Nb}_{2} \mathrm{O}_{5}$ and $\mathrm{Ta}_{2} \mathrm{O}_{5}$ is obtained with a $\mathrm{p}_{\mathrm{Cl} 2} / \mathrm{p}_{\mathrm{CO}}$ ratio of approximately 1 .

- The carbochlorination kinetics of the poor concentrate is slower than those of the rich concentrate, due to the formation of a layer of diffusion of solid and/or liquid chlorides $(\mathrm{Ca}$, Mn, etc.)

\section{Acknowledgements}

The authors would like to thank P. Blazy, C. Houzé, R. Solozabal, J.C. Múgica (INASMET, San Sebastián) and Ruiz-Ayucar, E. (CENIM). They also express their thanks to A. Bonazebi, M. Djona, S. Ivanaj, N. Kanari, N. Menad and N. Mirghafari N. (LEM-GPE), for discussion and suggestions, S. Dominiak, Université de Metz, J.M. Claude and A. Kohler of l'Université de Nancy for analysis of the samples by SEM, and F. Lhote (CNRS-CRPG) for XRD analyses.

\section{REFERENCES}

(1) Tolley, R.J. Advances in tantalum and niobium technology. Tantalum, Niobium International Study Center, $\mathrm{N}^{\circ}$ 69, 1992.

(2) Stienning, R. Niobium in the superconducting super collider. Conf. on Tantalum and Niobium, T.I.C, Orlando, FL, (USA), 1988: 725-745.

(3) Albrecht, W.W. et al. Pollution control in tantalum/niobium chemistry. Tantale-Niobium International Study Center, 12/1990, Bulletin $N^{\circ} 64$, 1990: 5-9.

(4) Tolley, R.I. Tantalum in tin slags: a review. Int. Conf. on Tantalum and Niobium, T.I.C, Orlando, FL, (USA), 1988: 197-219.

(5) Allain, E. Recyclage des pentoxydes de tantale et de niobium contenus dans les scories de four à étain par un traitement hydro-pyromettalurgique. Tesis. Université de Nancy I, Nancy (France), 1993: 136.

(6) L.R. de Freitas and F. Ajersch. Chem. Eng. Common. J. 30 (1-2), 1984: 19-33.

(7) Srinivasan, K.R., Jena P.K. Trans. Indian Inst. Metals J., 21 (3), 1968: 35.

(8), RoInE, A. Outokumpu HSC Chemistry for windows. Version 2.0. Outokumpu Research, Pori (Finland), 1994.

(9) Szekely, J., Evans, J.W. and Sohn, H.Y. Gas-solid reactions. Academic Press. New York, 1976: 115-7 and 232-39.

(10) Soleiman, M.K. and RaO, I.K. Metall. Trans., 18 B, 70, 1987: 459-470.

(11) Landsberg, A., Hoatson, C.L. and Block, F.E. Metall. Trans., Vol. 3, 02/72, 1972: 517-523.

(12) De Freitas, L.R. and Ajersch, F. Chem. Eng. Common J., 30, (1-2), 1984: 19-33.

(13) Duona, M. Tesis, INPL, Nancy, (France) 1994: 182 pp.

(14) Gaballah, I., Allain, E. and Duona, M. Chlorination kinetics of refractory metal oxides $\left(\mathrm{MoO}_{3}, \mathrm{Nb}_{2} \mathrm{O}_{5}, \mathrm{Ta}_{2} \mathrm{O}_{5}\right.$ and $\mathrm{V}_{2} \mathrm{O}_{5}$ ). Light Metals, Proc. of the technical sessions. TMS Light Metals Committee, 123rd TMS Annual Meeting San Francisco, Feb. 27-March 3 1994: 11531161. Edited by Ulrich Mannweiler. Published by TMS. 